\title{
The Effect of Modifyng Child Oriented Hospital Environments to Prevent the Impact of Hospitalization in Medan, North Sumatra
}

\author{
Farida Linda Sari Siregar ${ }^{1}$, Febrina Oktavinola Kaban ${ }^{2}$ \\ ${ }^{1,2}$ Lecturer of Maternity and Pediatric Nursing Departmen, University of Sumatera Utara, Indonesia \\ farida.linda@ymail.com \\ febrinak@gmail.com
}

\begin{abstract}
Modify the child oriented hospital environments can increase the fun, feeling safe and comfortable environment for the child so that the child is always evolving and feel comfortable in their environment. The purpose of this study was to identify the effect of modifyng child oriented hospital environments to prevent the impact of hospitalization in Medan, North Sumatra. This research is Quasi-experimental using posttest-only control group design. This study used two groups of subjects ie intervention and control groups, the first group was untreated and the other groups being treated. Samples of this study were 40 school-age children (6-12 years), respectively the control group and the intervention as much as 40 respondents. Sampling technique is random sampling. Intervention is provided wallhanging cartoons, colourful nurse clothes, bed linen, cartoonspatterned pillowcases and comic books. Data was analyzed using independent " $t$ " test with $\alpha=0.05$. The result showed, in the control group the average impact hospitalization 10.10 with a standard deviation of 3.13 , while the intervention group on average the impact of hospitalization 1.13 with a standard deviation of 1.12 ( $p$ value $=\mathbf{0 . 0 0 1}$ ). Conclusion of this research is that modifying thor being e hospital environment nuanced child can prevent the impact of hospitalization on children in Medan North Sumatra.
\end{abstract}

Keywords - children, environmental modifications, the impact of hospitalization

\section{INTRODUCTION}

Hospitalization in children is a stressful experience for both the children themselves and their parents. The number of stressors experienced by children when undergoing hospitalization interfere adversely affecting the child's development. Hospitalization may be considered to be a threatening experience and is a stressor, and may lead to a crisis for children and families. This condition may occur because the unknown the unknown, stress with the change of the status of health, environment, daily habits and limited coping mechanisms. Children will react when illness and hospitalization. These reactions such as fear for being separated from family and friends, far having to stay in an unknown and unpleasant environment, for undergoing examinations and treatments and for losing their self determination. are influenced by the level of development, previous experience, the support system in the family, coping skills and severity illness [1]. Principles of atraumatic care is divided into four, namely: preventing or reducing the impact of separation between parents and children, with family centered approach, improve the ability of people old in her care to control, prevent or minimize the physical and psychological injury (pain) as well as modify the physical environment nuanced child [7].

Feelings that can arise is the lack of control that resulted in threat perception and can affect children's coping skills. Loss of control at school children, among others, caused many routines in hospitals such as bedrest imposed, the use of bedpans, inability to choose menu, lack of privacy, bathing in bed, use of a wheelchair or gurney could lead to threats and loss of control at school children [9].

Ignorance of children and families to experience and the new situation as a result of hospitalization cause children and families experiencing stress. In addition, children in need of special care than other patients, so the time needed to care for children $20 \%-45 \%$ over time to treat adults [2].

Hospitalization was often confusing, complex and overwhelming for children and their families [4]. Thus, the nurse as one of the health care providers are constantly in touch with the patient, in providing care for children with hospitalization should focus on atraumatic care, by intervening to minimize stressors, maximize the benefits for 
hospitalization, provide psychological support to family members, and prepare children before hospitalized [9].

Atraumatic helpful care to prevent psychological problems (anxiety) and optimize the growth and development of children in hospitalization [1]. There is a strong correlation between the use of atraumatic care with decreased anxiety levels in children who underwent hospitalization [6]. The application of atraumatic care effect of reducing anxiety when infusion in children who underwent hospitalization [3].

The purpose of this study was to identify whether there is the effect of modifying the hospital environment nuanced child against impact prevention of hospitalization in children in Medan North Sumatra.

\section{METHODS}

This research is Quasi-experimental using posttest-only control group design. This study used two groups of subjects ie intervention and control groups, the first group was untreated and the other groups being treated. Samples of this study were 40 school-age children (6-12 years), respectively the control group and the intervention as much as 40 respondents. Sampling technique is random sampling. Intervention is provided wall hangings cartoon, nurse clothes multi color, bed linen, pillowcases patterned cartoons and comic books. The impact of hospitalization in children was measured using_questionnaire sheet of impact of school age children hospitalization containing 15 questions. Data was analyzed using independent " $\mathrm{t}$ test with $\alpha=0.05$.

\section{RESULTS}

The result showed, in the control group the average impact hospitalization 10.10 with a standard deviation of 3.13 , while the intervention group on average impact hospitalization 1.12 with a standard deviation of 1.13 ( $\mathrm{p}$ value $=0.001$ ).
TABLE I

THE EFFECT OF MODIFYING CHILD ORIENTED HOSPITAL ENVIRONMENTS TO PREVENT THE IMPACT OF HOSPITALIZATION IN MEDAN, NORTH SUMATRA $(\mathrm{N}=40)$

\begin{tabular}{|c|c|c|c|c|}
\hline Groups & Mean & SD & SE & P Value \\
\hline Control & 10.10 & 3.13 & 0.49 & 0.001 \\
\hline Intervention & 1.12 & 1.13 & 0.17 & \\
IV. DISCUSSION
\end{tabular}

The results showed that modifying the child oriented hospital environments can prevent the impact of hospitalization on children in Medan North Sumatra. Modify the physical environment nuanced children can increase the fun, feeling safe and comfortable environment for the child so that the child is always evolving and feel comfortable in their environment. Modifications type environment a child can do with the arrangement or decoration using looms and floral curtains or cute animals, wall hangings picture of the animal world, or fauna, nameplate patient funny picture, colored walls and the use of bright color in the room, and the stairs painted colourful [7].

Use of the health team uniforms of white can be a stressor for children, unfamiliar hospital environment for children and parents. So the use of multi-colored clothes nonconventional nurses preferred by children and parents whose children are hospitalized. In addition, a nurse's uniform color can improve parental perception of the reliability of the nurses where their use nonconventional nurses can contribute to improve the relationship of children and nurses [8].

\section{CONCLUSIONS}

Conclusion of this research is that modifying the hospital environment nuanced child can prevent the impact of hospitalization on children in Medan North Sumatra.

It is expected that the hospital make modifications to the physical environment nuanced so that children can increase the fun, feeling safe, comfortable environment for the child, the child is always evolving and feel comfortable in their environment.

\section{REFERENCES}

[1] H. Alimul dan A. Aziz, Pengantar Ilmu Keperawatan Anak. Salemba Medika. Jakarta. 2012.

[2] Aidar, N. Hubungan peran keluarga dengan tingkat kecemasan anak usia sekolah (6-12 tahun) yang mengalami hospitalisasi di ruang III 
Rumah Sakit Umum dr Pirngadi Medan. Skripsi. Universitas Sumatera Utara. 2011

[3] Breving, R. M. D., Ismanto, A. Y., \& Onibala, F. Pengaruh penerapan atraumatic care terhadap respon kecemasan anak yang mengalami hospitalisasi di RSU Pancaran Kasih GMIM Manado dan RSUP Prof dr R. D. Kandou Manado. E-journal keperawatan 3(2), Mei 2015.

[4] Kyle, T \& Susan, C. Buku ajar keperawatan pediatric vol 1, 2 Edisi 2. Jakarta: EGC. 2014

[5] Pantulu, P. Gambaran pengetahuan, sikap dan perilaku perawat tentang atraumatic care pada anak di RSUD Prof dr H Aloei Saboe kota Gorontalo. Skripsi. Universitas Hasanuddin. 2010.

[6] Rini, M. D., Sari, H. R., \& Rahmawati, I. Hubungan penerapan atraumatic care dengan kecemasan anak prasekolah saat proses hospitalisasi di RSU dr. H. Koesnadi Kabupaten Bondowoso. Skripsi. Universitas Jember. 2-13

[7] Supartini, Y. Buku ajar konsep dasar keperawatan anak. Jakarta: EGC. 2014.

[8] Utami, R. Hubungan penerapan atraumatic care dengan tingkat kepuasan orang tua anak selama proses hospitalisasi di Ruang Anak RSD Balung Jember. Skripsi. Universitas Jember. 2012

[9] Wong, D. L. Pedoman klinis keperawatan pediatrik edisi 4. Jakarta: EGC. 2013

[10] Wong, D. L., Eaton, M. H., Wilson, D., Winkelstein, M. L., \& Schwartz, P. Buku ajar keperawatan pediatrik. Volume 1 \& 2 edisi 6. Jakarta: EGC. 2009. 